\title{
Further Studies on the Luteotropic Action of Estrogen in Rats
}

\author{
KIYOHISA UCHIDA, MASUMI KADOWAKI, TAMOTSU MIYAKE AND \\ KATSUMI WAKABAYASHI* \\ Shionogi Research Laboratory, Osaka and \\ * Division of Pharmaceutical Sciences, National Institute of \\ Radiological Sciences, Chiba
}

\begin{abstract}
Synopsis
A single injection of $10 \mu \mathrm{g} / \mathrm{rat}$ of estradiol benzoate (EB) at $10.00 \mathrm{hr}$ on the day of estrus (designated as Day 1) in 4-day cyclic rats caused a marked increase in ovarian secretion of progesterone and a concomitant decrease in 20 $\alpha$-hydroxypregn-4-en-3-one secretion for over a week. Hypophysectomy on Day 3 completely diminished the secretion of progesterone on Day 5. The treatment with EB induced the surgy releases of prolactin and $\mathrm{LH}$ on the evening of Day 2 or 3, but no further release was seen thereafter. In pseudopregnant rats, a marked release of prolactin occurred between midnight and early morning, but any nocturnal release of neither prolactin, $\mathrm{LH}$, nor FSH was seen in the EB treated rats so far examined on Day 4 to 5 . Single injections with prolactin, $\mathrm{LH}$ and/or FSH on the evening of the first day of diestrus in cycling rats failed to sustain the luteal function. Pretreatment with progesterone, given an hour prior to the EB treatment, completely blocked the release of gonadotropins expected on Day 2 without reducing the elevated secretion of progesterone in the EB treated rats. These results suggest that the gonadotropins released on Day 2 can not be mediators for the luteotropic action of estrogen. Since hypophysectomy after EB treatment reduced ovarian secretion of progesterone to the basal level, it is presumed that estrogen maintains luteal function by acting on the luteal tissue in the presence of hypophyseal factors.
\end{abstract}

Previously, we have demonstrated that estradiol benzoate (EB) injected on the day of estrus in 4-day cyclic rats prolongs luteal phase and sustains ovarian secretion of progesterone over a week (Uchida et al., 1970). This gives a direct evidence for the luteotropic action of estrogen which has been suggested by morphological and biological evidences (Bogdanove, 1966; Gilmore and McDonald, 1969). The luteotropic action of estrogen is generally assumed to be due to the stimulation of prolactin secretion (see Everett, 1966), since estrogen can increase the secretion of prolactin (Nicoll and Meites, 1964; Nagasawa et al., 1969; Chen and Meites, 1970) and

Received for publication February 12, 1973. prolactin can sustain the luteal function in the rat (Astwood, 1941; Malven, 1969; MacDonald et al., 1970; Armstrong et al., 1970). In fact, the luteotropic action of estrogen does not manifest in hypophysectomized rats, while daily treatments with prolactin can maintain progesterone secretion in either intact or hypophysectomized rats (Uchida et al., 1970). However, the release of prolactin in the EB treated rats is transient (Uchida et al., 1972) and thus it raises a question whether such a short lived surge of prolactin can maintain the luteal function for considerable periods such as over a week.

The present experiments were attempted to investigate whether the luteotropic action of estrogen is attributed to the release of prolactin or not. 


\section{Materials and Methods}

\section{Animals}

Wistar strain female rats of 9 weeks after birth were housed in an air conditioned room $\left(25 \pm 1{ }^{\circ} \mathrm{C}\right.$, $50-60 \%$ humidity) with free access to chow diet and bottled water. The room was lighted for exactly $12 \mathrm{hr}$ daily (08.00-20.00 hr). Vaginal smears were examined every morning and rats exhibiting regular 4-day estrous cycle were used after completing at least three normal cycles.

Estrogen, progesterone and gonadotropin treatment

Estradiol benzoate (EB) was dissolved in sesame oil and injected subcutaneously at $10.00 \mathrm{hr}$ on the day of estrus (designated as Day 1). Progesterone in sesame oil was injected subcutaneously at $9.00 \mathrm{hr}$ on Day 1. Ovine prolactin (NIH-P-S8, TZ-P*) and ovine FSH (NIH-FSH-S6) in saline were injected subcutaneously at $16.00 \mathrm{hr}$ on the first day of diestrus and ovine LH (NIH-LH-S14) was injected intravenously at $19.00 \mathrm{hr}$ on the same day.

\section{Determination of ovarian secretion of progestins}

Ovarian vein blood was collected for mostly 15 min under sodium methylhexabital anesthesia (125 $\mathrm{mg} / \mathrm{kg}$, i.p.) and the concentrations of progesterone

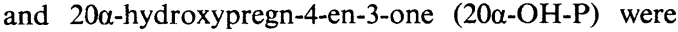
determined by gas-liquid chromatography after thinlayer chromatographic separation. The procedures were described in the previous paper (Uchida et al., 1969a).

\section{Determination of plasma gonadotropin concentra-} tions

Peripheral blood samples were collected by heart puncture under sodium methylhexabital anesthesia $(125 \mathrm{mg} / \mathrm{kg}$, i.p.) using heparin (20-30 units/tube) as an anticoagulant. Plasma concentrations of gonadotropins were determined in duplicate by radioimmunoassay procedures (Monroe et al., 1968) using NIAMD Radioimmunoassay Kits (NIAMD-Rat LH-I-1, Anti-Rat LH serum S-1, Rat LH-RP-1, NIAMD-Rat FSH-I-1, Anti-Rat FSH serum S-1, Rat FSH-RP-1, Rat Prolactin-I-1, Anti-Rat Prolactin serum S-1, Rat Prolactin-RP-1) and goat anti-rabbit gamma globulin serum purchased from Dainabot Radioisotope Lab., Ltd. (Tokyo). LH, FSH and prolactin levels have been expressed in terms of NIHLH-S1, NIH-FSH-S1, and NIAMD-Prolactin-RP-1, respectively.

* TZ-P: Ovine prolactin preparation purchased from Teikoku-Zoki Co. Ltd., Tokyo.

\section{Hypophysectomy}

Hypophysectomy was performed under sodium methylhexabital anesthesia $(125 \mathrm{mg} / \mathrm{kg}$, i.p.) by the trans-auricular method (Tanaka, 1955).

\section{Pseudopregnant rats}

Pseudopregnancy was induced by cervical stimulation utilizing a hand-vibrator on the morning of estrus (designated as Day 1).

\section{Results}

\section{1) Ovarian secretion of progesterone and $20 \alpha-O H-P$}

The sequential changes in ovarian secretory rates of progesterone and $20 \alpha-\mathrm{OH}-\mathrm{P}$ following the treatment with EB on Day 1 are shown in Figure 1. Progesterone secretion, being low on Day 1, significantly increased on Day 2 and then remained high until Day 7. Although the values after Day 3 were somewhat lower than the maximum value on Day 2, they were about 10 -fold or more of the basal level. In contrast with progesterone, $20 \alpha-\mathrm{OH}-\mathrm{P}$ secretion was highest on Day 1 and then decreased gradually to the lowest value on Day 7. Vaginal smears in these rats indicated diestrous signs so far examined. These data indicate that a single injection of EB shows a long-lasting luteotropic action in rats.

\section{2) Dependency of the luteotropic action of} $E B$ to the pituitary

In order to know whether the luteotropic action of EB depends on the pituitary or not, animals were hypophysectomized on Day 3 after EB treatment and the ovarian secretions of both progestins were determined on Day 5 . The results are given in Table 1. After hypophysectomy progesterone secretion completely decreased to the basal level, suggesting that the luteotropic action of EB requires the pituitary. On the other hand, $20 \alpha-\mathrm{OH}-\mathrm{P}$ secretion was slightly higher than the controls, as it was seen in the rats hypophysectomized before EB treatment (Uchida et al., 1970). 


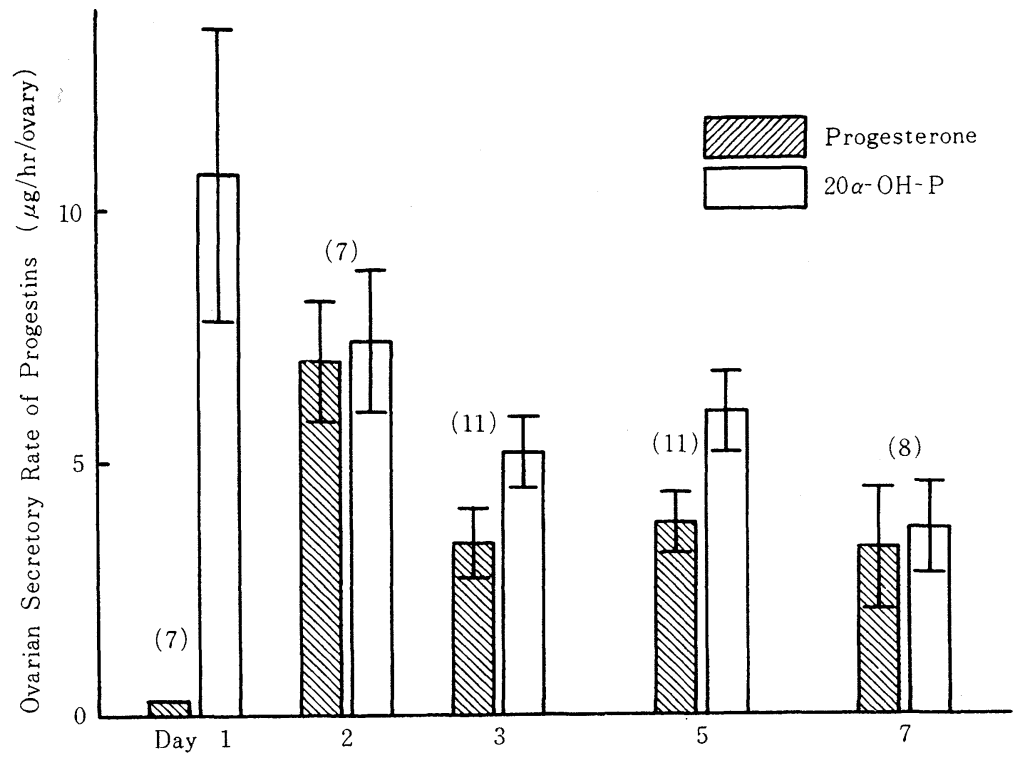

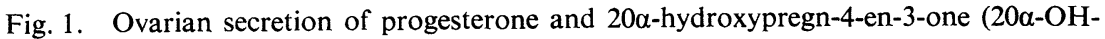
P) in rats given $10 \mu \mathrm{g} / \mathrm{rat}$ of estradiol benzoate (EB) at $10.00 \mathrm{hr}$ on the day of estrus (designated as Day 1). Determinations were performed at $15.00 \mathrm{hr}$ on the day indicated. Columns and bars indicate mean values and standard errors. Numbers of rats are given in parentheses.

Table 1. Effect of hypophysectomy on ovarian secretion of progesterone and $20 \alpha-\mathrm{OH}-\mathrm{P}$ in estradiol benzoate (EB) treated rats ${ }^{a}$

\begin{tabular}{|c|c|c|c|}
\hline & $\begin{array}{l}\text { No. of } \\
\text { rats }\end{array}$ & $\begin{array}{r}\text { Progesterone }{ }^{c)} \\
(\mu \mathrm{g} / \mathrm{hr} / \mathrm{o}\end{array}$ & $\begin{array}{l}20 \alpha-O H-P^{c)} \\
\text { vary) }\end{array}$ \\
\hline Control & 11 & $3.80 \pm 0.58^{d)}$ & $6.01 \pm 0.83^{d)}$ \\
\hline $\begin{array}{l}\text { Hypophy- } \\
\text { sectomized }^{b}\end{array}$ & 10 & $0.30 \pm 0.04$ & $8.55 \pm 0.85$ \\
\hline
\end{tabular}
a) A $10 \mu \mathrm{g} / \mathrm{rat}$ of EB was injected subcutaneously at $10.00 \mathrm{hr}$ on estrus (designated as Day 1).
b) Hypophysectomy was performed at $10.00 \mathrm{hr}$ on Day 3.
c) Progesterone and 20 $\alpha-\mathrm{OH}-\mathrm{P}$ secretions were determined at $15.00 \mathrm{hr}$ on Day 5 .
d) Mean \pm S.E.

\section{3) Gonadotropin release in $E B$ treated rats}

The mean plasma concentrations of LH and prolactin in 4-day cyclic rats during the estrous cycle and in the rats given a single injection of EB on estrus (Day 1) are shown in Table 2. In cycling rats, plasma LH concentration was markedly high on the afternoon of proestrus, but it was quite low in the other stages. Prolactin concentration also increased on proestrus, and it increased again on estrus. The increase of prolactin on estrus was apparently different from that on proestrus, as the estrous increase was noted only in a half or one third of the rats while the proestrous increase was seen in all of the rats. When rats were given a single injection of EB on Day 1, both gonadotropins markedly increased on Day 2 giving values comparable to the preovulatory increase in cyclic rats. Plasma LH concentration returned to the basal level on Day 3 and remained low thereafter, but prolactin showed high values again on Day 3 and then decreased. No further increase was found thereafter in plasma gonadotropin levels so far examined.

Table 3 shows the diurnal changes of plasma gonadotropins on Day 5 to 6 in pseudopregnant rats and on Day 4 to 5 in the EB treated rats. A marked increase of prolactin was found in pseudopregnant rats during the period from 

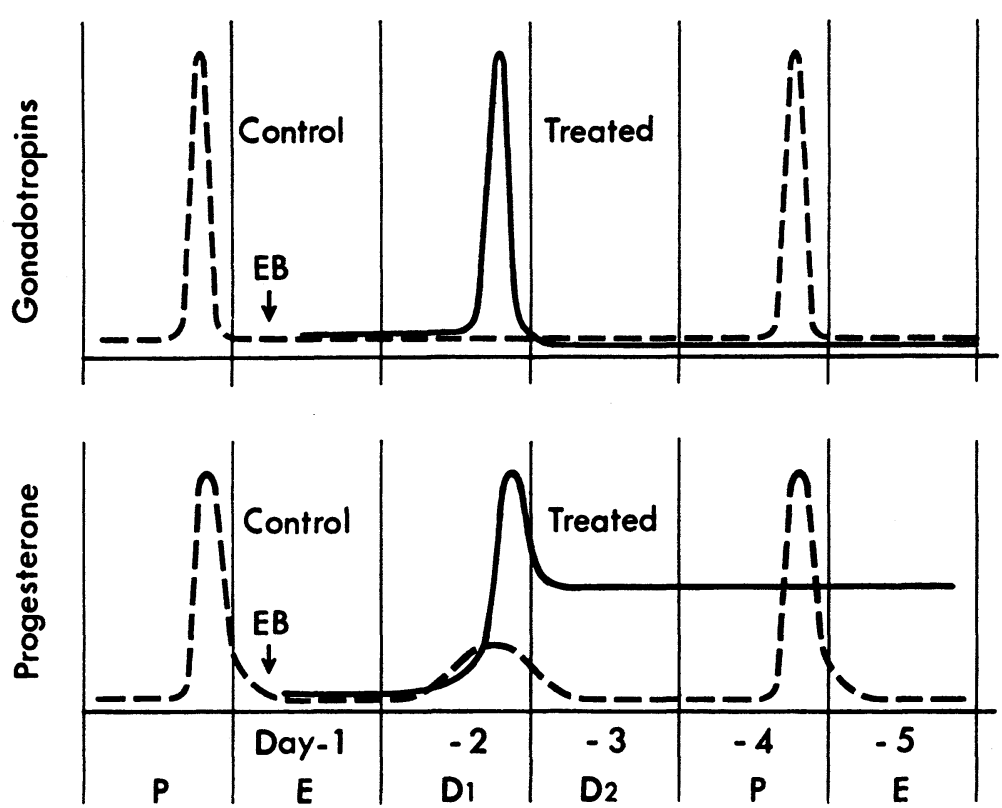

Fig. 2. A schematic representation for chronological relations between gonadotropin release and progesterone secretion in control (broken line) and estradiol benzoate (EB) treated rats (solid line). A $10 \mu \mathrm{g} / \mathrm{rat}$ of EB was injected subcutaneously at $10.00 \mathrm{hr}$ on the day of estrus (designated as Day 1).

Table 2. Plasma LH and prolactin concentrations in rats given estradiol benzoate (EB) on Day 1 and in control rats

\begin{tabular}{|c|c|c|c|c|c|}
\hline \multirow{2}{*}{\multicolumn{2}{|c|}{$\begin{array}{l}\text { Day and time of } \\
\text { determination }\end{array}$}} & \multicolumn{2}{|c|}{$\mathrm{LH}(\mathrm{ng} / \mathrm{m} l)$} & \multicolumn{2}{|c|}{ Prolactin $(\mathrm{ng} / \mathrm{m} l)$} \\
\hline & & \multirow{2}{*}{$\frac{\text { Control }}{0.63 \pm 0.09^{b)}}$} & \multirow{2}{*}{$\frac{\text { EB treated }{ }^{a)}}{<0.50^{b)}}$} & \multirow{2}{*}{$\frac{\text { Control }}{77.7 \pm 33.5^{b)}}$} & \multirow{2}{*}{$\frac{\text { EB treated }}{(a)}$} \\
\hline Day $1(\mathrm{E})$ & $19.00 \mathrm{hr}$ & & & & \\
\hline \multirow{5}{*}{ Day $2\left(D_{1}\right)$} & $15.00 \mathrm{hr}$ & & $0.87 \pm 0.03$ & & $139.4 \pm 19.3$ \\
\hline & $17.00 \mathrm{hr}$ & & $6.04 \pm 0.75$ & & $112.5 \pm 31.2$ \\
\hline & $19.00 \mathrm{hr}$ & $<0.50$ & $9.79 \pm 1.12^{c)}$ & $36.0 \pm 7.2$ & $81.0 \pm 9.5^{c)}$ \\
\hline & $21.00 \mathrm{hr}$ & & $3.23 \pm 0.21^{b)}$ & & $47.4 \pm 7.1^{b)}$ \\
\hline & $23.00 \mathrm{hr}$ & & $0.91 \pm 0.13$ & & $<5.5$ \\
\hline Day $3\left(\mathrm{D}_{2}\right)$ & $19.00 \mathrm{hr}$ & $0.69 \pm 0.09$ & $0.53 \pm 0.01$ & $15.7 \pm 7.0$ & $85.9+13.2$ \\
\hline Day $4(\mathrm{P})$ & $19.00 \mathrm{hr}$ & $9.32 \pm 1.54$ & $<0.50$ & $70.4 \pm 13.6$ & $6.0 \pm 0.4$ \\
\hline Day 5 & $19.00 \mathrm{hr}$ & & $<0.50$ & & $17.1 \pm 4.1$ \\
\hline
\end{tabular}

a) A $10 \mu \mathrm{g} / \mathrm{rat}$ of EB was injected subcutaneously at $10.00 \mathrm{hr}$ on the day of estrus (designated as Day 1) into 4-day cyclic rats. Gonadotropins were determined in blood samples obtained by cardiac puncture under sodium methylhexabital anesthesia $(125 \mathrm{mg} / \mathrm{kg}$, i.p.) and expressed in terms of NIH-LH-SI and NIAMD-Prolactin-RP-1.

b) Mean \pm S.E. in 6 rats.

c) Mean $:$ S.E. in 12 rats.

midnight to the early morning, but no increase of prolactin was found in the EB treated rats.
Neither LH nor FSH increased in both groups of rats. 
Table 3. Diurnal changes of plasma prolactin, $\mathrm{LH}$ and FSH levels in pseudopregnant rats and estradiol benzoate (EB) treated rats

\begin{tabular}{|c|c|c|c|c|}
\hline \multicolumn{2}{|c|}{$\begin{array}{l}\text { Day and time of } \\
\text { determination }\end{array}$} & $\begin{array}{l}\text { Prolactin } \\
(\mathrm{ng} / \mathrm{m} l)\end{array}$ & $\underset{(\mathrm{ng} / \mathrm{m} l)}{\mathbf{L H}}$ & $\underset{(\mathrm{ng} / \mathrm{m} l)}{\mathrm{FSH}}$ \\
\hline \multicolumn{5}{|c|}{ i) Pseudopregnant rats } \\
\hline \multirow[t]{2}{*}{ Day 5} & $19.00 \mathrm{hr}$ & $42.1 \pm 19.03^{a)}$ & $0.38 \pm 0.05^{a)}$ & - \\
\hline & $23.00 \mathrm{hr}$ & $85.7 \pm 20.57$ & $0.59 \pm 0.06$ & $38 \pm 19.5^{a)}$ \\
\hline \multirow[t]{3}{*}{ Day 6} & $3.00 \mathrm{hr}$ & $143.9 \pm 26.20$ & $0.46 \pm 0.05$ & $38 \pm 12.4$ \\
\hline & $7.00 \mathrm{hr}$ & $166.9 \pm 17.65$ & $0.75 \pm 0.30$ & $77 \pm 16.5$ \\
\hline & $11.00 \mathrm{hr}$ & $32.7 \pm 8.90^{b)}$ & - & - \\
\hline \multicolumn{5}{|c|}{ ii) EB treated rats } \\
\hline Day 4 & $23.00 \mathrm{hr}$ & $7.5 \pm 0.84^{a)}$ & $0.44 \pm 0.15^{a)}$ & $51 \pm 31.3^{a)}$ \\
\hline \multirow[t]{2}{*}{ Day 5} & $3.00 \mathrm{hr}$ & $15.0 \pm 3.62$ & $0.45 \pm 0.01$ & $53 \pm 26.3$ \\
\hline & $7.00 \mathrm{hr}$ & $16.5 \pm 7.32$ & $0.67 \pm 0.12$ & $44 \pm 17.0$ \\
\hline
\end{tabular}

a) Mean \pm S.E. in 5 rats.

b) Mean \pm S.E. in 3 rats.

Table 4. Effects of prolactin, $\mathrm{LH}$ and/or FSH on ovarian secretion of progesterone and $20 \alpha-\mathrm{OH}-\mathrm{P}$ in intact 4 -day cyclic rats

\begin{tabular}{|c|c|c|c|}
\hline Treatment & $\begin{array}{l}\text { No. of } \\
\text { rats }\end{array}$ & \multicolumn{2}{|c|}{ ( $\mu \mathrm{g} / \mathrm{hr} /$ ovary) } \\
\hline Control & 7 & $0.29 \pm 0.04^{f)}$ & $6.27 \pm 1.04^{f)}$ \\
\hline Prolactin $^{a)}$ & 5 & $0.18 \pm 0.01$ & $6.25 \pm 1.29$ \\
\hline Prolactin $^{b)}$ & 6 & $0.43 \pm 0.04$ & $10.36 \pm 0.93$ \\
\hline $\mathrm{LH}^{c)}$ & 7 & $0.46 \pm 0.05$ & $6.54 \pm 1.05$ \\
\hline $\mathrm{FSH}^{d)}$ & 7 & $0.52 \pm 0.08$ & $11.49 \pm 2.48$ \\
\hline Prolactin $^{a)}+\mathrm{LH}^{c)}$ & 7 & $0.44 \pm 0.04$ & $4.83 \pm 0.46$ \\
\hline Prolactin $^{(b)}+\mathrm{LH}^{(c)}+\mathrm{FSH}^{d)}$ & 5 & $0.26 \pm 0.02$ & $11.98 \pm 1.96$ \\
\hline Prolactin $^{e)}$ multiple injection & 7 & $4.85 \pm 1.27$ & $9.30 \pm 1.08$ \\
\hline
\end{tabular}

a) A $10 \mathrm{IU} /$ rat of prolactin (Ovine prolactin purchased from. Teikoku-Zoki Co. Ltd. Tokyo) was injected subcutaneously at $16.00 \mathrm{hr}$ on diestrus 1 .

b) A $200 \mu \mathrm{g} / \mathrm{rat}$ of NIH-P-S8 was injected subcutaneously at $16.00 \mathrm{hr}$ on diestrus 1 .

c) A $10 \mu \mathrm{g} /$ rat of NIH-LH-S14 was injected intravenously at $19.00 \mathrm{hr}$ on diestrus 1 .

d) A $200 \mu \mathrm{g} / \mathrm{rat}$ of NIH-FSH-S6 was injected subcutaneously at $16.00 \mathrm{hr}$ on diestrus 1 .

e) A $200 \mu \mathrm{g}$ of NIH-P-S8 was injected subcutaneously twice a day (10.00 and $18.00 \mathrm{hr})$ for 5 times starting at $10.00 \mathrm{hr}$ on estrus.

f) Ovarian secretory rates of progestins were determined at $19.00 \mathrm{hr}$ on the day following injection. In the case of multiple injections, the determination was performed at $19.00 \mathrm{hr}$ on the last day of the injection. Values are expressed as Mean \pm S.E.

4) Effects of single injections with gonadotropins on the ovarian secretion of progesterone and $20 \alpha-O H-P$

Since EB induced the release of gonadotropins at the evening of Day 2, it was examined whether single injections with prolactin, LH and/or FSH on diestrus 1 can produce the hyperfunction of corpora lutea or not. The results are given in Table 4.

Single injections with prolactin, LH and FSH, alone or combined, failed to increase the secretion of progesterone at $19.00 \mathrm{hr}$ on diestrus 2 (the day corresponding to Day 3 in EB treated rats), while multiple injections with prolactin starting on the day of estrus increased progesterone secretion. 
Table 5. Effect of progesterone on the stimulative effect of estradiol benzoate (EB) on gonadotropin release in rats

\begin{tabular}{cccc}
\hline \hline Dose of progesterone $^{a)}$ & No. of rats & LH $(\mathrm{ng} / \mathrm{m} l)$ & Prolactin $(\mathrm{ng} / \mathrm{m} l)$ \\
\hline $0 \mathrm{mg}$ & 5 & $8.07 \pm 0.97^{b)}$ & $168.4 \pm 19.52^{b)}$ \\
$1 \mathrm{mg}$ & 5 & $2.02 \pm 0.31$ & $45.5 \pm 8.26$ \\
$10 \mathrm{mg}$ & 5 & $0.40 \pm 0.04$ & $17.4 \pm 3.93$ \\
\hline
\end{tabular}

a) A $10 \mu \mathrm{g} / \mathrm{rat}$ of EB was injected subcutaneously at $10.00 \mathrm{hr}$ on the day of estrus (designated as Day 1) and doses of progesterone indicated in the table were injected subcutaneously at $9.00 \mathrm{hr}$ on the day. Gonadotropins were determined at $19.00 \mathrm{hr}$ on Day 2.

b) Mean \pm S.E.

Table 6. Effect of progesterone pretreatment on ovarian secretion of progesterone and $20 \alpha-\mathrm{OH}-\mathrm{P}$ in estradiol benzoate (EB) treated rats

\begin{tabular}{lccc}
\hline Treatment & $\begin{array}{c}\text { No. of } \\
\text { rats }\end{array}$ & $\begin{array}{c}\text { Progesterone } \\
(\mu \mathrm{g} / \mathrm{hr} / \mathrm{ovary})\end{array}$ \\
\hline $\mathrm{Control}^{c}$ & 13 & $0.23 \pm 0.02^{d)}$ & $9.29 \pm 1.27^{d)}$ \\
$\mathrm{EB}^{(a)}$ & 6 & $3.66 \pm 0.76$ & $10.84 \pm 1.20$ \\
$\mathrm{~EB}^{a)}+$ Progesterone $^{b)}$ & 7 & $5.67 \pm 0.77$ & $10.96 \pm 1.31$ \\
\hline
\end{tabular}

a) A $10 \mu \mathrm{g} / \mathrm{rat}$ of EB was injected subcutaneously at $10.00 \mathrm{hr}$ on estrus (designated as Day 1).

b) A $10 \mathrm{mg} / \mathrm{rat}$ of progesterone was injected subcutaneously at $9.00 \mathrm{hr}$ on Day 1 .

c) Progesterone and $20 \alpha-\mathrm{OH}-\mathrm{P}$ secretions were determined at $15.00 \mathrm{hr}$ on Day 3 .

d) Mean \pm S.E.

5) Effect of progesterone pretreatment on the stimulative effect of $E B$ on gonadotropin release and progesterone secretion

When exogenous progesterone was given an hour prior to the EB treatment, the elevation of plasma gonadotropins expected at the evening on Day 2 was blocked completely by a dose of $10 \mathrm{mg}$ of progesterone and incompletely by $1 \mathrm{mg}$ (Table 5). However, the pretreatment with $10 \mathrm{mg}$ progesterone did not reduce but rather enhanced the elevated secretion of progesterone on Day 3 in the EB treated rats (Table 6).

\section{Discussion}

The present experiments demonstrated that the luteotropic action of estrogen requires the pituitary, but can not be attributed to the action of prolactin, $\mathrm{LH}$, or FSH released in response to the estrogen treatment.

Estrogen, when injected into 4-day cyclic rats, sustains the hyperfunction of corpora lutea for a considerable period (Fig. 1). This agrees well with the findings of Bogdanove (1966) or Gilmore and McDonald (1969) or other workers demonstrating that the treatment with estrogen maintains large functional corpora lutea and results in a prolonged vaginal diestrus. When rats are hypophysectomized on Day 1 just before EB treatment, no increase in ovarian progesterone secretion occurs (Uchida et al., 1970). When rats are hypophysectomized on Day 3 after EB treatment, progesterone secretion on Day 5 is completely reduced (Table 1). These two experiments clearly indicate that the luteotropic action of estrogen is mediated via the pituitary, and hypophyseal substance(s) are indispensable for the activation and maintenance of corpora lutea.

On the other hand, the treatment with EB on Day 1 induces marked release of both $\mathrm{LH}$ and prolactin on Day 2 (Table 2), where the peak of $\mathrm{LH}$ is found at around $19.00 \mathrm{hr}$ and 
that of prolactin occurs somewhat earlier than LH. However, the release of gonadotropins on Day 2 are transient and no further release was found thereafter. When prolactin, LH and/or FSH are injected once at the evening of diestrus 1 to mimick the estrogen-induced gonadotropin surges on Day 2, no longlasting elevation in ovarian progesterone secretion is followed (Table 4). These treatments with gonadotropins, at least with LH or FSH, can cause an abrupt increase in ovarian progesterone out-put when examined an hour after the injection (Uchida et al., 1969b). Pretreatment with progesterone denied the stimulative action of EB on gonadotropin release (Table 5) but did not debase the luteotropic action of estrogen (Table 6). The treatment with progesterone alone did not seem to cause an increase in ovarian secretion of progesterone, since Kobayashi et al. (1969) demonstrated, using the rats in our breeding conditions, that progesterone treatment on estrus or diestrus 1 does not affect the timing of ovulation, while the treatment on diestrus 2 does delay ovulation by $48 \mathrm{hr}$. These results suggest that although prolactin possesses luteotropic action (MacDonald et al., 1970; Armstrong et al., 1970; Uchida et al., 1970) and $\mathrm{LH}$ is also required for the maintenance of corpora lutea (Loewit et al., 1969; Madhwa Raj and Moudgal, 1970; Yoshinaga et al., 1971), either gonadotropin, alone or combined, is unable to mediate the luteotropic action of estrogen.

Recently, it has been clearly demonstrated that prolactin is nocturnally released during the whole period of pseudopregnancy (Freeman and Neill, 1972) and early period of pregnancy (Butcher et al., 1972), indicating that progesterone secretion in these rats is maintained by prolactin. This is confirmed by the present experiment demonstrating that a marked increase of plasma prolactin level is found between midnight and early morning in pseudopregnant rats (Table 3). However, no periodic release of prolactin was found in the EB treated rats (Table 3), suggesting that the luteotropic action of estrogen is not entirely due to the release of prolactin.

Chronological relations between gonadotropin release and progesterone secretion in both control and EB treated rats are schematically shown in Figure 2. The maximal secretion of progesterone at $19.00 \mathrm{hr}$ on Day 2 in the EB treated rats is brought by the acute steroidogenic action of LH (Armstrong et al., 1964; Marsh et al., 1966; Yoshinaga et al., 1967; Uchida et al., 1969b) released at this time (Table 2), and the long-lasting secretion of progesterone following its marked peak on Day 2 reflects the corpora lutea being functional. Since no ovulation occurs after the surge of LH on Day 2 (Uchida et al., 1972), there is no doubt that the prolonged secretion of progesterone originates from the corpora lutea formed after ovulation on Day 1 and exposed to the surge of LH on Day 2, suggesting that LH is not necessarily luteolytic.

The luteotropic action of estrogen, therefore, may be explained by its action on the corpora lutea, which is maintained by the base line levels of circulating pituitary factors including $\mathrm{LH}$ and prolactin.

\section{Acknowledgement}

The authors wish to express their appreciation to Dr. Bun-ichi Tamaoki (National Institute of Radiological Sciences) for his kind help in measuring gonadotropins. We also appreciate the generous supplies of NIH-LH-S14, NIH-FSH-S6 and NIHProlactin-S8 from the Endocrinology Study Section, National Institute of Health, U.S.A., and of the materials for radioimmunoassay from National Institute of Arthritis and Metabolic Diseases, National Institute of Health, U.S.A.

\section{References}

Armstrong, D. T., J. O'Brien and R. O. Greep (1964). Endocrinology 75, 488.

Armstrong, D. T., K. A. Knudsen and L. S. Miller (1970). Ibid. 86, 634.

Astwood, E. B. (1941). Ibid. 28, 309. 
Bogdanove, E. M. (1966). Ibid. 79, 1011.

Butcher, R. L., N. W. Fugo and W. E. Collins (1972). Ibid. 90, 1125.

Chen, C. L. and J. Meites (1970). Ibid. 86, 503.

Everett, J. W., In Harris, G. W. and B. T. Donovan (eds), The Pituitary Gland, Vol. 2, University of California Press, Berkeley and Los Angeles, 1966, p. 166.

Freeman, M. E. and J. D. Neill (1972). Endocrinology 90, 1292.

Gilmore, D. P. and P. G. McDonald (1969). Ibid. 85, 946.

Kobayashi, F., K. Hara and T. Miyake (1969). Endocrinol. Japon. 16, 251.

Loewit, K., S. Badawy and K. Laurence (1969). Endocrinology. 84, 244.

MacDonald, G. J., A. H. Tashjian, Jr., and R. O. Greep (1970). Biology of Reproduction 2, 202.

Madhwa Raj, H. G. and N. R. Moudgal (1970). Endocrinology 86, 874.

Malven, P. V. (1969). Ibid. 84, 1224.

Marsh, J. M., G. Telegdy and K. Savard
(1966). Nature 212, 950.

Monroe, S. E., A. F. Parlow and A. R. Midgley Jr., (1968). Endocrinology 83, 1004.

Nagasawa, H., C. L. Chen and J. Meites (1969). Proc. Soc. Exp. Biol. Med. 132, 859.

Nicoll, C. S. and J. Meites (1964). Ibid. 117, 579.

Tanaka, A. (1955). Ann. Rept. Shionogi Res. Lab. 5, 154.

Uchida, K., M. Kadowaki and T. Miyake (1969a). Endocrinol. Japon. 16, 227.

Uchida, K., M. Kadowaki and T. Miyake (1969b). Ibid. 16, 239.

Uchida, K., M. Kadowaki and T. Miyake (1970). Ibid. 17, 509.

Uchida, K., M. Kadowaki, T. Miyake and K. Wakabayashi (1972). Folia Endocrinol. Japon. 47, 813 (In Japanese).

Yoshinaga, K., S. A. Grieves and R. V. Short (1967). J. Endocrinol. 38, 423.

Yoshinaga, K., N. R. Moudgal and R. O. Greep (1971). Endocrinology 88, 1126. 